system over telephone lines between two buildings in New York which are two miles apart. Even when perfected, it is not certain whether there would be a commercial demand by the public for a costly facility which would enable them to see the person telephoning. At the General Electric Company's laboratories at Schenectady, experiments are being made on the transmission of television signals along a light beam instead of by wire or radio. Nothing very novel has recently been published in connexion with cathode ray television. The National Broadcasting Company is building a new television studio on the eighty-fifth floor of the Empire State Building at a height of 1,000 feet above the street. The short-wave transmitting aerial is on the top of the airship mooring mast and is 1,250 feet above the street. The received images will be six inches square and will be seen directly on the end of a cathode ray tube. Transmissions will be made from the Empire State studio on wave-lengths of $5-7 \cdot 5$ metres.

\section{Supply Undertakings and the Grid}

Is an article in the Times Trade and Engineering Supplement for November 19, Mr. Charles D. Taite, of the Lancashire Electric Power Company, discusses the grid from the point of view of the supply undertakings affected by it. We are glad to learn that the supply undertakings, several of which strongly opposed the Act of 1926, are now willing to co-operate with the Central Electricity Board in making the schemes which have been carried out under the provisions of the Act a success. This is wise, seeing that they pay the whole of the charges in connexion with the grid and are therefore vitally interested in its success. Since the Act came into operation, a wave of industrial depression has swept over the world and although the use of electricity in Great Britain has continued to expand, the growth is less than it would have been under normal conditions. In some areas, factories have closed down. In textile areas, many mills have gone permanently out of commission. On the Clyde and the Tyne, shipbuilding has fallen on evil days. On the other hand, new openings have been found for electrical development; rural electrification has commenced and electricity is being more widely used by the householder. But beneficial as these developments are, their effect is comparatively insignificant compared with the enormous growth which would take place with a return to good trading conditions. Some indication of what might be expected was experienced in the textile areas of Lancashire last autumn, following the revival which took place in the demand for textile goods. The load on many undertakings expanded by 15 per cent, and had the revival been maintained throughout the year, another 15 per cent improvement would have been reached. The heavier the load the less will the supply companies' fixed charges per unit to the Central Electricity Board be and the cost of electricity would be cheaper. In Mr. Taite's opinion, there is still an almost unlimited field for electrical enterprise.

\section{Outdoor Museums in the United States}

Public museums in the United States of America have been increasing in numbers in recent years at the rate of one every fortnight, and their standard of efficiency as educational agencies has been rising. The American Association of Museums has been taking stock of the museum resources of the country, and has made available a considerable mass of new statistical information on which the Association's director, L. V. Coleman, has based an interesting report on "Recent Progress and Condition of Museums". This has been published by the United States Office of Education as Bulletin No. 30, 1931. Among recent developments is the appearance of museums of science in national parks. The underlying idea of these is that museums attempt, too often without success, to tell indoors, with the aid of objects that are fragments or imitations, stories that should be told where Nature has provided genuine illustrative exhibits. 'Trailside' museums, each given over to a restricted subject, are found to be more useful for some kinds of instruction than cases in a museum building. The first demonstration was made a few years ago in the Yosemite, and the most recent is an extensive series of 'trailsides' in the Yellowstone National Park. Simultaneously with this exploitation of the resources of the national parks, museums in cities have been moved to search local parks for natural features that can be explained on the spot. The influence of the movement has spread into the field of history also, as in the George Washing. ton birthplace national monument, and a newly appointed park historian is developing history educa. tion, just as the park naturalist has developed natural history education. The number of museums doing good educational work a decade ago was not more than a dozen; now it is in the hundreds.

\section{The Auckland Museum and Institute, New Zealand}

The Auckland Institute and Museum, now in its second year of occupation of the fine Memorial Building, has of necessity been undergoing a revision of its extensive collections. But in addition it has been able to carry out a very successful expedition for the investigation of the natural history and ethnology of the northernmost portion of the North Auckland peninsula (Annual Report for 1931-32). Another notable activity of the staff is the furthering of the educational side of the Museum by lectures within the building and in the district, the Sunday afternoon public lectures having proved specially attractive; as well as by the formation of clubs for boys and girls, the preparation of exhibits for schools, and the arrangement of special exhibitions. An exhibition of antique plate, chiefly of the seventeenth and eighteenth centuries, increased the attendance by a thousand a week during its course; the weekly average number of visitors throughout the year was 2,856. The membership, like that of most similar bodies, shows a slight falling off in numbers, but the present roll still includes 588 names, 157 representing life members with a capital subscription fund exceeding $£ 2,000$. 